\title{
EDITORS' REMARKS
}

Much has been written on the military and diplomatic course of the second great world conflict, and special aspects of it, such as the Holocaust and the origins of the Cold War, have yielded small libraries. The Churchillian "blood, sweat, and tears" and similar patriotic invocations in every belligerent country were calls to arms, which presumed but did not honor the vast effort on the homefront necessary to wage total war. The nature of this effort, its significance for society in general, and the central role played by the laboring populations have hardly been explored. There are exceptions, of course, and Angus Calder's The People's War 1929-1945 (London, 1969) and Ruth Milkman's Gender at Work: The Dynamics of Job Segregation by Sex during World War II (Urbana, Ill., 1987) readily come to mind. But a large array of topics on the social history of the war await study in a national and comparative context: problems of labor mobilization; conditions in the workplace; women in the work force; effects on the family; changing moral values; mentalités and mythologies; resistance struggles; interventions by the state. The list could easily be doubled; our task is to begin the exploration. To that end, $I L W C H$ presents three essays of a very diverse nature in the hope of stimulating further interest and stirring up some controversy.

Geoffrey Field's essay "explores the centrality of class in the family imagery of the 1940s and the extent to which the 'crisis of family,' so widely debated during these years, was implicitly or explicitly construed as a problem of the workingclass family." Field punctures the myth that wartime Britain was one big and happy family, responding to the common danger and the promise of greater equality and social compassion. In contrast to such rosy images of the national family, he offers an analysis of the severe pressures on the traditional working-class family brought on by: separation, recruitment of women into the labor force, state interventions, the impact of bombing, full employment, and higher wages. His discussion of the dramatic social impact of mass evacuation and the negative views among officials, journalists, social workers, and middle-class social policy groups of the workingclass family's putative disintegration ("neglected evacuees, delinquent youths and 'good time girls' running wild in the blitzed cities, unfaithful wives and incompetent slum mothers," as well as sexual promiscuity and divorce) offers a fresh view of wartime dislocations and social attitudes about them.

Janet Hart's study explores the conditions of wartime German occupation in Greece, under which women were drawn into the resistance. She offers a picture of the resistance organizations as social movements that challenged the rigid class and gender structures of traditionalist Greek society. Due to the restricted participation in Greek political life, which was controlled by elites functioning through male-dominated, clientele networks, the Greek National Liberation Front (EAM) attracted broad, cross-class support. "By appealing to a defensive nation-

International Labor and Working-Class History

No. 38 , Fall 1990 , p. 1-2

(C) 1990 by the Board of Trustees of the University of Illinois 
alism, which cut across both class and gender barriers, the EAM's leaders gained the opportunity to alter communal beliefs regarding women's participation in politics and to raise the issue of women's activity in the public sphere." But female participation in the EAM - the small window of freedom in the prison of family life - was only made possible by the EAM adopting the existing strict social and moral codes that applied to women. Yet, their resistance experience offered women opportunities for freedom and self-definitions previously undreamt of and created a climate of rising expectations. These hopes were later crushed during the civil war (1946-1949) and thereafter in a political and social backlash in which former female resistance fighters were branded as enemies of the state.

Richard Rice's overview covers the period 1937-1945, when Japan was at war. The integration of Japanese labor into the political command structure was made easy by the small proportion ( 6.2 percent) of organized industrial workers. Though the National Mobilization Law of 1938 established firm control over labor, it also provided the means to intervene in labor-management disputes to guarantee industrial harmony. All attempts to maximize war production foundered, however, because of the ideological bias against military deferment of skilled industrial workers. Moreover, as in Nazi Germany, overlapping and conflicting bureaucratic agencies prevented the government from exercising total control over labor or production. The Japanese Industrial Patriotism Association (Sanpō) partly succeeded in creating a harmonious climate to serve national goals. In response to drastically worsening conditions, some workers engaged in various forms of onthe-job resistance; most bore the hardships stoically.

All three essays suggest a strong postwar legacy of the wartime experience: in Britain a primary concern with family policy; in Greece a backlash against changing mores concerning women; and in Japan a continuation of labor passivity on behalf of national interest.

An interesting contrast in labor mobilization was offered in Sheila Fitzpatrick's essay, "War and Society in Soviet Context: Soviet Labor before, during and after World War II" (ILWCH, 35). In the USSR, she argued, total mobilization originated with the Five-Year Plans and continued during postwar reconstruction.

In response to critics of his controversial essay on mass culture (ILWCH, 37), Michael Denning explicates and confirms his original argument about the "ending of mass culture." The concept "mass culture," he argues, has been made redundant by the extraordinary success of the culture industries, which have succeeded in reducing all forms of culture, whether high, popular, or mass, to cultural commodities. Denning's fresh view has by no means closed the controversy about mass culture. The subject is of vital importance to the study of the working class in this century. We plan to return to it in the near future and examine empirical work from the new theoretical perspectives. 